\title{
German students to pay for funding boost...
}

Munich. The German government last week proposed a budget which would effectively give the ministry for education and research (BMBF) a 2.3 per cent funding increase next year, with basic research enjoying a 3 per cent growth. These figures contrast with a suggested reduction of 1.3 per cent in overall public spending, the first country's first budget reduction since 1953 .

But only part -0.6 per cent, from DM15.53 billion (US $\$ 11$ billion) to DM15.62 billion - of this proposed growth would come as cash. The rest would be met out of savings in the cost of governmentsponsored student loans, proposed in a controversial bill drawn up by research minister Jürgen Rüttgers, which would introduce for the first time interest charges on loans.

The opposition social democrat party (SPD), which has pledged to increase support for research and technology by 10 per cent if elected to power, says that it will reject the bill when it goes before the Bundesrat, Germany's second chamber made up of representatives of the 16 Länder, where the SPD has a majority.

Peter Glotz, the party's education and research spokesman, says that Rüttgers is asking students to pay for the building-up of his ministry. He has called instead for a broad debate on the future financing of education, addressing the needs for a basic reform of a system which can no longer support a recent spurt in student numbers.

Changes to the student loan system known as BAföG, an abbreviation of Bundesausbildungsföderungsgesetz - are a sensitive topic. Universities in particular have reacted angrily to the BAföG bill, described by Hans-Uwe Erichsen, president of the University Rektors Conference, as "totally unacceptable". This view has wide public support. The influential newspaper, the Süddeutsche Zeitung, described Rüttgers' juggling of the accounts as "a cheap trick".

But Rüttgers has tried to deflect such criticism by promising that the DM1.6 billion that could be raised over the next five years by requiring interest to be paid on loans would be used to increase support for universities and science - a move which he hopes his critics will approve of.

In particular, Rüttgers wants some of this money to be used for university building and equipment. Although the Länder are responsible for the running costs of their own universities, capital investment is shared equally between federal and Länder governments.

This system came under strain this year when the federal government put a cap on its share of investments which the Länder say is unreasonably low (see Nature 353, 95; 1995). Rüttgers clearly hopes the prospect of this cap being raised may make the Län- der drop their resistance to his BAföG bill. University building and special university research programmes are together marked for a 2.5 per cent increase in 1996.

According to Rüttgers' plan, both basic and applied research would benefit from his proposed funding changes, being earmarked for a 3 per cent and 3.8 per cent rise respectively. Two particular beneficiaries would be the Max Planck Society, which runs basic research institutes, and the Deutsche Forschungsgemeinschaft, to both of which Rüttgers has promised a 5 per cent increase if the BAföG bill is passed (see below).

More significantly, he has also promised to maintain this rate of increase for each of the following four years, to provide a constantly growing budget. But whether this will materialize depends on the agreement of the Länder governments, which cofinance the two organizations.
Rüttgers is also proposing to increase government spending on biotechnology, information technology and environmental research, in line with promises made in his first statement on research policy since he took office last November (see Nature 373, $648 ; 1995)$.

Funding of space research will not increase under his proposed budget - but neither will it decrease. Rüttgers says that "the BMBF thereby underlines its role as a reliable partner in, and ensures finances for, a realistic concept of European space programmes".

The BAföG bill will be discussed in the Bundesrat after summer. If it is rejected, as many are currently predicting, Rüttgers will be left with a budget rise that will be substantially below inflation. He refuses to comment on what his priorities would be in such a case.

Alison Abbott

\section{...as scientists hope for the best}

Bonn. "Politicians have discovered the 'future factor'", says Wolfgang Frühwald, president of the Deutsche Forschungsgemeinschaft (DFG), the organization which funds most university research in Germany. "That is why we are predicting a rise in research funds in next year's budget".

Frühwald is particularly optimistic about the renewal of the so-called five-byfive agreement, under which both the DFG and the Max Planck Society had been guaranteed a five Frühwald: optimistic per cent inc- on future prospects. rease in budget

for the five years 1991 to 1995 .

Last week's promise by the government to renew its side of the agreement until 1999, provided parliament approves a controversial bill to impose interest on student loans (see above), supports his optimism.

Speaking at the annual meeting of the DFG two weeks ago, Frühwald said that a guaranteed increase of five per cent a year is needed as a basis for future policy, particularly given the extra responsibilities which the DGF shares with the Max Planck Society for research in the new Länder.

But the renewal of the five-by-five agreement does not depend on Bonn, as financing for both organizations is shared equally between federal and Länder governments, and finance ministries in some Länder have not been enthusiastic about such a major commitment.

The Länder are expected to make their final decision after the summer. But several influential figures spoke in favour at the DFG annual meeting. They included Johannes Rau, prime minister of Nordrhein-Westfalen, and Hans Zehetmair, science minister of Bavaria.

According to Frühwald, another optimistic sign is the support from Anke Brunn, deputy chairwoman of the Bund-Land Commission (BLK), the body which brokers decisions on education and science between federal and Länder governments.

A renewal of the agreement would mean an additional DM447 million for the DFG, which is already planning how best it could be spent. Two weeks ago, the DFG opened up talks with the Blue List institutes in east Germany to find a way of ensuring that they have more chance of winning DFG grant money.

According to Ingolf Hertel, director of the Max Born institute for non-linear optics in east Berlin, and spokesman for the Blue List institutes, a possible rule change is now being discussed which would allow scientists at the institutes to apply to the DFG for money for research projects that are in line with the main research interests of their institutes. This cannot be done under current DFG rules. "But it all hangs on the renewal of the five-by-five agreement" , says Hertel. A. A. 